\title{
Predicting the attitude towards electronic banking continued usage intentions among rural banking customers in South Africa
}

\begin{tabular}{|c|c|}
\hline \multicolumn{2}{|c|}{$\begin{array}{l}\text { Authors: } \\
\text { Anele Nkoyi }{ }^{1} \text { (1) } \\
\text { Madele Tait }{ }^{2} \text { (1) } \\
\text { Freda van der Walt }{ }^{3} \text { (1) }\end{array}$} \\
\hline \multicolumn{2}{|c|}{$\begin{array}{l}\text { Affiliations: } \\
{ }^{1} \text { Department of Business } \\
\text { Management, Central } \\
\text { University of Technology, } \\
\text { South Africa }\end{array}$} \\
\hline \multicolumn{2}{|c|}{$\begin{array}{l}{ }^{2} \text { School of Management } \\
\text { Sciences, Nelson Mandela } \\
\text { University, South Africa }\end{array}$} \\
\hline \multicolumn{2}{|c|}{$\begin{array}{l}{ }^{3} \text { Faculty of Management } \\
\text { Sciences, Central University } \\
\text { of Technology, South Africa }\end{array}$} \\
\hline \multicolumn{2}{|c|}{$\begin{array}{l}\text { Corresponding author: } \\
\text { Anele Nkoyi, } \\
\text { ankoyi@cut.ac.za }\end{array}$} \\
\hline \multicolumn{2}{|c|}{$\begin{array}{l}\text { Dates: } \\
\text { Received: } 13 \text { July } 2018 \\
\text { Accepted: } 18 \text { Sept. } 2018 \\
\text { Published: } 24 \text { Jan. } 2019\end{array}$} \\
\hline \multicolumn{2}{|c|}{$\begin{array}{l}\text { How to cite this article: } \\
\text { Nkoyi, A., Tait, M. \& Van der } \\
\text { Walt, F., 2019, 'Predicting the } \\
\text { attitude towards electronic } \\
\text { banking continued usage } \\
\text { intentions among rural } \\
\text { banking customers in South } \\
\text { Africa', South African Journal } \\
\text { of Information Management } \\
\text { 21(1), a1016. https://doi.org/ } \\
\text { 10.4102/sajim.v21i1.1016 }\end{array}$} \\
\hline \multicolumn{2}{|c|}{$\begin{array}{l}\text { Copyright: } \\
\text { C 2019. The Authors. } \\
\text { Licensee: AOSIS. This work } \\
\text { is licensed under the } \\
\text { Creative Commons } \\
\text { Attribution License. }\end{array}$} \\
\hline \multirow[b]{2}{*}{ 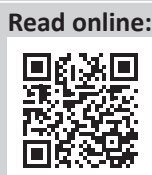 } & \\
\hline & $\begin{array}{l}\text { Scan this QR } \\
\text { code with your } \\
\text { smart phone or } \\
\text { mobile device } \\
\text { to read online. }\end{array}$ \\
\hline
\end{tabular}

Background: The proliferation of electronic banking has revolutionised the delivery of financial services across the globe. E-banking services offer substantial benefits, such as reduced costs to transact, convenience and flexibility. Despite the considerable penetration of e-banking in South Africa, it remains unclear whether customers are willing to continue using these services, particularly given the safety concerns, because of the high incidence of cybercrime.

Objectives: Owing to the paucity of research on customers' attitude towards continued usage intentions of e-banking services, the aim of this study is to investigate the formation of attitude towards e-banking continued usage intentions among rural banking customers.

Method: The study was underpinned by a positivist paradigm, and a descriptive design was employed. Primary data were collected by means of self-administered questionnaires, which yielded 139 valid responses. Regression analysis was utilised during the analysis for hypothesis testing.

Results: The results revealed that e-banking attitude is mainly driven by perceived ease of use and perceived usefulness. Furthermore, the results showed that e-banking attitude strongly predicts continued usage intentions.

Conclusion: The empirical evidence presented in this study adds value to the existing research on e-banking, particularly in the context of rural banking customers, an area which is largely under-researched in South Africa.

\section{Introduction}

The advent of the internet has created unprecedented opportunities for businesses of all kinds, including retail banks, to interact with and create sustainable relations with their customers (Jara, Parra \& Skarmeta 2014). Generally, there is acknowledgement among scholars and practitioners that the proliferation of electronic banking (e-banking) services has revolutionised the delivery of financial services across the globe. A number of scholars (Maduku 2016; Nel \& Boshoff 2014; Singh \& Srivastava 2018; Tran \& Corner 2016) share the sentiment that e-banking services provide added value to customers by offering substantial benefits, such as reduced costs to transact, convenience and flexibility. However, despite the penetration of e-banking in South Africa, a trend which has also been noted globally, a sizable number of customers from rural areas still rely on traditional branch-based banking (Mlitwa \& Tshetsha 2012; Ramavhona \& Mokwena 2016). This problem can be attributed to a multiplicity of factors, but lack of access to the internet is the main one. For instance, Statistics South Africa (2015) reported that while 16\% of households in metropolitan areas had access to the internet, only $1.2 \%$ of households in the rural areas enjoyed the same access. The survey further revealed that households were generally more likely to have access to the internet at work than at home or at internet cafés and educational institutions.

Even though e-banking is a widely discussed phenomenon in the literature, there is still a paucity of research predicting attitude formation towards e-banking continued usage intentions in the context of rural customers. Moreover, most of the existing studies in South Africa (see Maduku 2016; Moodley \& Govender 2016; Nel, Boshoff \& Raleting 2012) that have explored the phenomenon of e-banking or its components have been conducted in urban areas. Owing to the mentioned research gap, little is known about attitude formation and its effect on continued usage intentions from the perspective of rural banking customers. Consequently, this study investigates whether attitude is a key predictor of continued usage intentions of e-banking services in rural areas, and what factors drive such attitudes. Attitudes have a significant influence on behaviour, 
and they affect the way an individual judges and reacts towards other objects and events (Roberts-Lombard \& Parumasur 2017). Thus, the thesis advanced in this study is that customers' attitude plays a key role in predicting e-banking continued usage intentions. Maduku (2013) contends that existing studies in South Africa (e.g. Brown \& Molla 2004; Green \& Van Belle 2003; Singh 2004) have paid little attention to identify and predict the factors that influence customers' attitude towards e-banking services. Therefore, the aim of this study is to empirically investigate determinants of attitude formation towards continued usage intentions among rural banking customers. To realise this aim, this study posits that attitude strongly predicts e-banking continued usage intentions. This is based on the theoretical proposition in Davis' (1989) technology acceptance model (TAM). There is a need for a study of this nature, because it will add value to the existing research on e-banking, particularly in the context of rural customers, an area which is largely under-researched in South Africa.

\section{Literature review}

\section{Background on e-banking services}

The 21st century has been characterised by rapid use of information technology, which has revolutionised a wide spectrum of working and living environments (Adam 2013; Khater, Almansour \& Mahmoud 2016). Likewise, the trend in the banking industry has been to gradually replace over-thecounter banking with new electronic delivery channels (Yu \& Guo 2008). Particularly since the early 1990s, many banks have started to embrace electronic technology, in order to make banking easier for customers (Maduku 2013). In the year 2000, about $80 \%$ of the banks in the United States of America (USA) were already offering e-banking services, and customer use of these services was slowly growing. The Bank of America became the first bank to top 3 million online banking customers, more than $20 \%$ of its customer base, in 2001 (Keivani et al. 2012:63). In South Africa, e-banking has gradually taken off since 1996, and consumers have been attracted to the convenience, safety and lower costs of these services (Redlinghuis \& Rensleigh 2010:2). According to Singh (2004:190), ABSA was the first bank to offer online services, followed by Nedbank. Standard Bank, First National Bank and Mercantile Bank followed suit. Since then, South Africa has been recording gradual penetration in usage of e-banking services. For instance, a report compiled by World Wide Worx (2004), cited in Brown and Molla (2004), indicates that the number of online bank accounts in South Africa passed the 1 million mark towards the end of 2003, with an average annual growth of $29 \%$. Worth noting is that numbers of e-banking customers have been increasing over the years. For instance, the 2015 FinScope consumer survey on financial services indicates that smartphones were the most used communication devices; $40 \%$ of the respondents used a banking app and 29\% used cell phone banking to manage their finances (FinScope South Africa 2015:5). The question, however, is whether customers intend to continue using e-banking services, and what the determining factors are for such intentions.

\section{Theoretical basis and operationalisation of the model constructs}

This study was theoretically anchored by Davis' (1989) TAM. The overarching principle behind the TAM is that it specifies a basis for discovering the influence of external variables, such as perceived usefulness and perceived ease of use, on internal beliefs, namely customer's attitudes and intentions (Maduku 2016). The TAM has been found to be the most useful and robust model to explain and predict acceptance and use of technology. However, the challenge concerning the TAM is that researchers have overlooked essential determinants of decisions and actions, and have turned a blind eye to inherent limitations in the TAM (Bagozzi 2007). In spite of wide acknowledgement of the TAM as an influential theoretical lens to study technology adoption and usage behaviour, there has been little effort to consider certain marketing factors that can help to enhance customers' attitude towards technology adoption and continued usage behaviour. A study conducted by Wahab et al. (2009:124) revealed that customer relationship management performance significantly influences e-banking adoption. Wahab et al. (2009) recommended that future studies should consider integrating customer relationship management performance in research of e-banking adoption behaviour and usage behaviour. Accordingly, two essential ingredients for building customer relationships, namely relationship trust and relationship commitment, are integrated with the traditional salient TAM beliefs about technology, namely perceived usefulness and perceived ease of use. Relationship trust and relationship commitment were identified because the success of a business relationship lies in the development and growth of trust and commitment among partners (Berndt \& Tait 2014:29). Perceived price value was also added in the study, because price plays a key role in shaping customers' attitude towards products and services (McDaniel, Lamb \& Hair 2006). In this study, e-banking attitude is operationalised as the main predictor of e-banking continued usage intentions among rural banking customers. The hypothetical model of the study is shown in Figure 1.

The research model depicted in Figure 1 postulates that e-banking continued usage intentions are predicted by customers' attitude towards e-banking continued usage intentions, while e-banking attitude is driven by salient

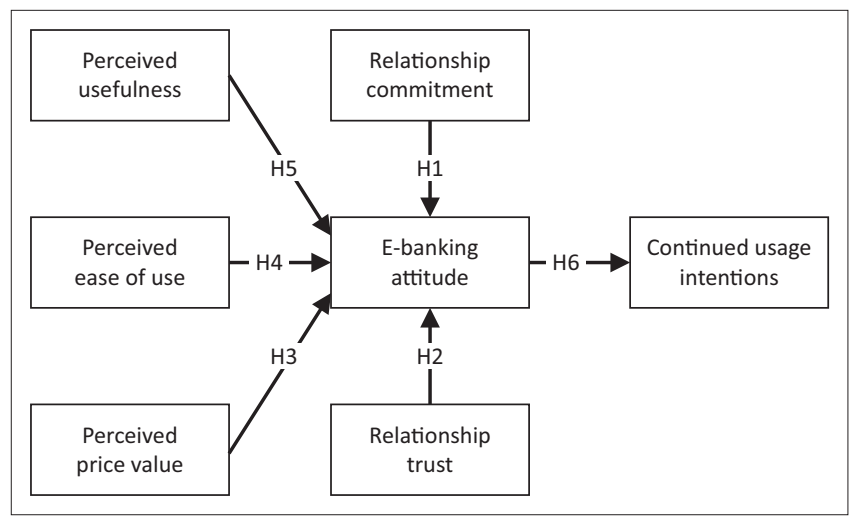

FIGURE 1: The research model. 
beliefs (perceived usefulness and perceived ease of use) and perceived price value of e-banking services. Relationship trust and relationship commitment are theorised to influence customers' attitude towards e-banking continued usage intentions. Based on the model in Figure 1, six hypothesis statements are proposed in subsequent sections, and the model constructs are operationalised.

\section{Relationship trust and relationship commitment}

The commitment-trust theory of relationship marketing (Morgan \& Hunt 1994) maintains that relationships exist through the retention of trust and commitment. Thus, when both of these are present, not just one or the other, they can produce outcomes that promote efficiency, productivity and effectiveness. For this reason, relationship commitment and relationship trust are considered essential ingredients for building successful customer relationships. Hence, the two are often discussed together in the relationship marketing literature (see Berndt \& Tait 2014; Egan 2011; Morgan \& Hunt 1994), with few scholars mentioning one without the other. Hence, the same precedent will be followed in this study. Berndt and Tait (2014:29) define trust as the willingness to rely on an exchange partner in whom one has confidence. This means that for retail banks, building trust is done to ensure that customers will stand behind their promises regarding e-banking services. Commitment is the belief that the importance of a relationship with another is so significant that it warrants maximum effort to maintain it (Buttle 2009). Commitment and trust lead directly to cooperative behaviours, which are conducive to relationship marketing success (Berndt \& Tait 2014). As such, the following hypotheses regarding relationship commitment and relationship trust are posited:

H1: Relationship commitment is positively related with e-banking attitude.

H2: Relationship trust is positively related with e-banking attitude.

\section{Perceived price value}

In its narrowest sense, price can be defined as the amount of money charged for a product or service, but more broadly, price is the sum of all the values that customers give up in order to gain the benefits of using a product or service (Kotler, Armstrong \& Tait 2010). Accordingly, McDaniel et al. (2006) argue that price may also be the time lost while waiting to acquire goods and services. In the retail banking context, for instance, price may be the time spent by banking customers in long queues when traditional branch-based banking is preferred to e-banking. Marketers grapple with the challenge of setting reasonable prices, in particular owing to a wide range of pricing strategies, to maintain customer patronage; as such, the concept of price has long been an area of interest among scholars (Ali, Amin \& Ryu 2015; Kotler et al. 2010; Lamb et al. 2015; McDaniel et al. 2006).

Despite price being an important predictor of consumer behaviour, not much research has been conducted on its impact in predicting e-banking continued usage behaviour and intentions. For the purposes of this study, we posit that perceived price value positively affects consumers' attitude towards e-banking continued usage behaviour, because customers have to bear the costs associated with the purchase of devices and services (data). The proposition is consistent with Venkatesh, Thong and $\mathrm{Xu}$ (2012), who proposed and tested integration of price value to address the cost issue of technology use in consumer settings. As such, the following hypothesis is posited:

H3: Perceived price value has a positive effect on customers' e-banking attitude towards continued usage intentions.

\section{Perceived ease of use and perceived usefulness}

According to the information systems (IS) literature, customers' attitude towards e-banking has been proven to be determined by two salient beliefs, namely perceived ease of use and perceived usefulness, in South Africa (Maduku 2016; Nel et al. 2012). The pioneer of the TAM, Davis (1989), defines perceived ease of use as the degree to which an individual believes that using a particular system will be free from mental effort. In effect, perceived ease of use in this context is customers' assessment that e-banking services are easy to use and require little effort. Perceived usefulness is the degree to which an individual believes that using a particular system will enhance his or her job performance; as such, perceived usefulness is the user's subjective probability that using a specific technology will increase his or her job performance (Davis 1989). The body of literature (Agwu 2015; Maduku 2013; Nel et al. 2012) indicates that these two salient beliefs are key determinants of technology adoption. These salient beliefs are operationalised to predict the attitude towards e-banking continued usage intentions. As such, the following hypotheses are posited:

H4: Perceived ease of use has a positive and statistically significant effect on e-banking attitude.

H5: Perceived usefulness has a positive and statistically significant effect on e-banking attitude.

\section{Attitude towards e-banking and continued usage intentions}

An attitude is a person's enduring favourable or unfavourable evaluations, emotional feelings and action tendencies towards a certain behaviour (Roberts-Lombard \& Parumasur 2017). The attitude-intention relationship is a phenomenon that is grounded in the behavioural component in the study of structural composition of customer attitudes. According to Schiffman, Kanuk and Wisenblit (2010), the behavioural component is concerned with the customer's intentions to take a specific action or behave in a certain way regarding an attitude object, which in this case is e-banking continued usage intentions. As a result, there is consensus among scholars on the attitude-intention relationship, and there is a significant body of empirical support for it (Mpinganjira et al. 2013; Pavlou \& Fygenson 2006; Roberts-Lombard \& Parumasur 2017), especially in the e-banking literature (Maduku \& Mpinganjira 2012; Nel et al. 2012; Sahoo \& Pillai 2017). As consumer behavioural intentions are of great concern to 
marketers, because they help in predicting how customers will act towards a company's products and services in future (Mpinganjira et al. 2013), the belief is held that customers' attitude is a strong predictor of e-banking continued usage intentions. The following hypothesis is thus proposed:

H6: Customers' e-banking attitude is positively related with continued usage intentions.

\section{Research methodology Philosophical standpoint}

This study adopted the ontological assumption that there is a reality that can be apprehended and that relations behind social reality can therefore be determined. In effect, the belief is held that meaningful indicators of what is actually happening regarding e-banking continued usage intentions among rural banking customers can be brought into being. Our epistemological stance is that knowledge should be gathered through verification of facts and that relationships and fundamental laws should govern the development of new knowledge (Tien 2009). Thus, the study was underpinned by a positivist research philosophy.

\section{Research design, data-gathering and data-analysis techniques}

A descriptive research design was adopted to describe the quantitative data, and, as such, a self-administered structured questionnaire was used as the data-collection instrument. The data-collection instrument (the questionnaire) contained two sections. The first section solicited the demographic profile of the respondents, and the second section contained five-point Likert-scale items. In the second section of the questionnaire, respondents were required to indicate their level of agreement or disagreement with certain statements, using the options ' 1 ' ('strongly agree'), '2' ('agree'), '3' ('neutral'), '4' ('disagree') or '5' ('strongly disagree'). Data were collected by means of self-administered questionnaires, which yielded 139 valid responses. During data analysis, reliability and convergent validity were assessed, and regression analysis was utilised to conduct the prediction analysis and for hypothesis testing.

\section{Results and discussion \\ Reliability and validity of the data-collection instrument}

Reliability, or internal consistency, of the research instrument was assessed by means of Cronbach's alpha correlation coefficients. Field (2013) suggests that the Cronbach's alpha index indicates the extent to which all items in the measuring instrument are measuring the same characteristic and that the set of variables is consistent within what it is intended to measure. Despite the debates around what is an acceptable threshold to ensure satisfactory reliability, in marketing research, values between 0.70 and 0.80 normally indicate good reliability (Iacobucci \& Churchill 2010; Malhotra 2010). Accordingly, the reliability analysis was conducted on seven scales, where their items were used to measure the internal consistency of each construct. The results are presented in Table 1.

Table 1 summarises the reliability of the data-collection instrument. The results demonstrate that all constructs are internally consistent in their measurement, as all the reported Cronbach's alpha values were above 0.7, which is an indication of good reliability. After the internal consistency of the data-collection instrument was assessed, the scales were subsequently submitted to exploratory factor analysis, to assess the validity of the instrument. Principal component analysis with a varimax rotation showed that there are six factors with eigenvalues above 1 . The Kaiser-Meyer-Olkin measure of sampling adequacy $(\mathrm{KMO}=0.902)$ indicated that the sample fits the factor analysis. The validity results show that the items loaded well into the scales, with the exception of relationship commitment 1 (RC1), perceived ease of use 1 (PEU1) and perceived ease of use 2 (PEU2). All other items reported factor loadings above 0.5 , which are regarded as satisfactory factor loadings (Field 2013). This is confirmed by high corrected item-total correlation values, which are all above the acceptable threshold of 0.5. As such, these two indicators account for satisfactory convergent validity of the scales.

However, the factor analysis extracted six factors instead of seven, because the constructs attitude and perceived usefulness were found in the same factor, suggesting that the model might have a problem of multicollinearity of the scales. For this reason, before proceeding with the hypothesis testing through multiple linear regression analysis, the assumption of multicollinearity needs to be tested. Multicollinearity is the extent to which a variable can be explained by the other variables in the analysis. In effect, as multicollinearity increases, it complicates the interpretation of the variate because it is more difficult to ascertain the effect of any single variable, owing to their interrelationships (Hair et al. 2014). A multicollinearity test was conducted to assess if there is a similar correlation between independent variables. Multicollinearity can be assessed by examining the tolerance and the variance inflation factor (VIF). The value of the tolerance should be above 0.1 , and the value of the VIF is expected to be below 10 . The multicollinearity test results are presented in Table 2.

Table 2 represents the multicollinearity of the six independent variables, namely relationship commitment, relationship trust, perceived cost value, perceived ease of use, perceived

TABLE 1: Reliability of the data-collection instrument.

\begin{tabular}{lcccc}
\hline Scale & Mean & $\begin{array}{c}\text { Standard } \\
\text { deviation }\end{array}$ & $\begin{array}{c}\text { Cronbach's } \\
\text { alpha }\end{array}$ & $\begin{array}{c}\text { Number } \\
\text { of items }\end{array}$ \\
\hline Relationship commitment & 2.27 & 0.83 & 0.859 & 5 \\
Relationship trust & 2.22 & 0.86 & 0.885 & 5 \\
Perceived price value & 2.38 & 0.98 & 0.893 & 5 \\
Perceived ease of use & 2.24 & 0.87 & 0.873 & 4 \\
Perceived usefulness & 1.93 & 0.87 & 0.824 & 4 \\
E-banking attitude & 2.08 & 0.88 & 0.933 & 5 \\
Continued usage intentions & 2.06 & 0.92 & 0.919 & 5 \\
\hline
\end{tabular}


usefulness and e-banking attitude. The results indicate that there is no multicollinearity issue found in all the presented variables, because the value of the tolerance for each variable is above 0.1 , and the value of the VIF is below 10 .

\section{Descriptive statistics and correlation results}

The descriptive statistics on the demographic characteristics of the respondents indicate that most of the people who participated in the study were women $(61.0 \%)$, followed by men $(39.0 \%)$, and that most of the respondents were degree holders $(33.1 \%)$. The age group that dominated the study was $26-35$ years $(57.4 \%)$. The majority of the respondents were Capitec Bank account holders (45.6\%). The results further show that e-banking is mostly used to check account balances $(72.8 \%)$, buy prepaid airtime $(72.8 \%)$ and transfer cash $(70.6 \%)$. It is evident from the descriptive statistics that most of the respondents tended to strongly agree with the scale items for e-banking perceived usefulness $($ mean $=1.93 ; \mathrm{SD}=0.87)$ and to agree with the items for relationship commitment $($ mean $=2.27 ; \mathrm{SD}=0.83$ ) and relationship trust $($ mean $=2.22 ; \mathrm{SD}=0.98)$. Likewise, the respondents tended to agree with the scale items for perceived price value $($ mean $=2.06 ; \mathrm{SD}=098)$ and attitude (mean $=2.08 ; \mathrm{SD}=0.88)$. The respondents also tended to agree that they will continue using e-banking (mean $=2.06$; $\mathrm{SD}=0.92$ ). The scale items for all the constructs were positively worded. Before running the regression analysis to test the hypotheses, a correlation test was conducted to ascertain the relationships between the constructs. The results are presented in Table 3.

A correlation coefficient indicates the strength of the relationship between two metric variables (Hair et al. 2014). A correlation coefficient of less than 0.1 (or > -0.1) is considered unsubstantial or negligible, one between 0.1 and 0.3 (or between -0.3 and -0.1) is considered small or weak, one

TABLE 2: Multicollinearity test results.

\begin{tabular}{lcc}
\hline Constructs & \multicolumn{2}{c}{ Collinearity statistics } \\
\cline { 2 - 3 } & Tolerance & VIF \\
\hline RT & 0.546 & 1.833 \\
RC & 0.475 & 2.105 \\
PEU & 0.390 & 2.561 \\
PV & 0.552 & 1.811 \\
PU & 0.386 & 2.591 \\
AT & 0.365 & 2.737 \\
\hline RT, relationship trust; RC, relationship commitment; PEU, perceived ease of use; PV, \\
perceived price value; PU, perceived usefulness; AT, attitude; VIF, variance inflation factor.
\end{tabular}

between 0.3 and 0.5 (or between -0.5 and -0.3 ) indicates a moderate effect and one of 0.5 or larger (or $\leq-0.5$ ) is considered to be strong (Lester 2007). According to Table 3, the correlations between the constructs were all positive and statistically significant at the 0.01 level. This, in effect, means that there is a $99 \%$ chance that these correlations do exist.

\section{Regression analysis and hypothesis testing}

Regression analysis is regarded as a statistical technique that predicts the values of one variable using the value of one or more other variables (Black 2011:583). As this study aimed to predict the attitude towards electronic banking continued usage intentions among rural banking customers, regression analysis was used to realise the aim of the research. In effect, the study sought to ascertain the extent to which the predictor variables (relationship commitment, relationship trust, perceived price value, perceived ease of use and perceived usefulness) could help to predict and explain customers' attitude towards continued usage intentions in a rural context. Nach (2009) suggests that regression analysis is an appropriate method of analysis when the goal of the research is to assess the extent of a relationship between a set of dichotomous or interval or ratio predictor variables on an interval or ratio criterion variable. It is for this reason that multiple regression analysis and linear regression analysis were utilised for hypothesis testing. The results of the two kinds of regression analysis are presented in Tables 4 and 5 .

The results in Table 4 reveal that the regression model predicting e-banking attitude is statistically significant $\left(F=45.164 ; R^{2}=0.621 ; p<0.001\right)$. The results indicate that the five predictors (relationship commitment, relationship trust, perceived price value, perceived ease of use and perceived usefulness) collectively predict and explain up to $62.1 \%$ of the variance on attitude. However, only perceived ease of use $(\beta=0.323 ; p<0.001 ; t=4.038)$ and perceived usefulness $(\beta=0.414 ; p<0.001 ; t=0.414)$ were found to have a significant effect on e-banking attitude. This means that the effect of relationship commitment, price value and relationship trust on attitude was found not to be statistically significant ( $p>0.05)$. This suggests that e-banking attitude is largely driven by perceived ease of use and perceived usefulness of e-banking. The results confirm previous empirical work conducted in South Africa regarding the phenomenon of e-banking, namely that the essential reason customers use e-banking is its perceived usefulness and its perceived ease

TABLE 3: Correlation matrix.

\begin{tabular}{|c|c|c|c|c|c|c|c|}
\hline Correlations & RT & RC & PEU & PV & AT & INT & PU \\
\hline Relationship trust (RT) & - & - & - & - & - & - & - \\
\hline Relationship commitment (RC) & $0.622 *$ & - & - & - & - & - & - \\
\hline Perceived ease of use (PEU) & $0.308^{*}$ & $0.527^{*}$ & - & - & - & - & - \\
\hline Perceived price value (PV) & $0.243^{*}$ & $0.435^{*}$ & $0.636^{*}$ & - & - & - & - \\
\hline Attitude (AT) & $0.441^{*}$ & $0.509 *$ & $0.690 *$ & $0.559 *$ & - & - & - \\
\hline Continued usage intentions (INT) & $0.498^{*}$ & $0.577^{*}$ & $0.617^{*}$ & $0.483^{*}$ & $0.727^{*}$ & - & - \\
\hline Perceived usefulness (PU) & $0.496 *$ & $0.544^{*}$ & $0.639 *$ & $0.525 *$ & $0.731^{*}$ & $0.589 *$ & - \\
\hline
\end{tabular}

RT, relationship trust; RC, relationship commitment; PEU, perceived ease of use; PV, perceived price value; AT, attitude; INT, continued usage intentions; PU, perceived usefulness.

*, All correlations are significant at the 0.01 level (two-tailed). 
TABLE 4: Multiple regression analysis to predict attitude towards e-banking.

\begin{tabular}{|c|c|c|c|c|c|c|}
\hline Predictor & Unstandardised coefficient & Standard error & Standardised coefficient & $t$ & $p$ & Decision on hypothesis \\
\hline Constant & 0.052 & 0.165 & - & 0.318 & 0.751 & - \\
\hline RC & -0.004 & 0.082 & -0.004 & -0.047 & 0.963 & H1 rejected \\
\hline RT & 0.114 & 0.073 & 0.111 & 1.563 & 0.120 & $\mathrm{H} 2$ rejected \\
\hline PV & 0.100 & 0.064 & 0.111 & 1.569 & 0.119 & $\mathrm{H} 3$ rejected \\
\hline PEU & 0.330 & 0.082 & 0.323 & 4.038 & $<0.001$ & H4 accepted \\
\hline PU & 0.419 & 0.078 & 0.414 & 0.414 & $<0.001$ & H5 accepted \\
\hline
\end{tabular}

Note: $R^{2}=0.621 ; F=45.164 ; p<0.001$.

$\mathrm{RC}$, relationship commitment; RT, relationship trust; PV, perceived price value; PEU, perceived ease of use; PU, perceived usefulness.

\begin{tabular}{|c|c|c|c|c|c|c|}
\hline Predictor & Unstandardised coefficient & Standard error & Standardised coefficient & $t$ & Significance & Decision on hypothesis \\
\hline Constant & 0.492 & 0.139 & - & 3.528 & $<0.001$ & - \\
\hline Attitude & 0.755 & 0.062 & 0.727 & 12.259 & $<0.000$ & H6 accepted \\
\hline
\end{tabular}

Note: $R^{2}=0.525 ; F=150.275 ; p<0.001$.

of use (Maduku 2013; Nel et al. 2012). Although these two customer beliefs are both statistically significant, the effect of perceived usefulness was found to be stronger than the effect of perceived ease of use. Therefore, banks need to maximise their efforts at improving customers' ease of use perceptions of e-banking.

In order to measure customers' e-banking continued usage intentions, as theorised in hypothesis 6, a linear regression analysis was conducted to evaluate the relationship between e-banking attitude and continued usage intentions after all the other variables were tested. The results show that the regression model predicting continued usage intentions is statistically significant $(F=150.275$; $\left.R^{2}=0.525 ; p<0.001\right)$. Particularly, the results demonstrate that attitude predicts and explains up to $52.5 \%$ of the variance on continued usage intentions and that customers' attitude strongly predicts continued usage intentions $(\beta=0.727 ; p<0.001 ; t=12.259)$. Hypothesis 6 is therefore accepted. This confirms and is consistent with the attitudeintention relationship literature that customer attitudes towards products and services are strong predictors of future behaviour.

\section{Theoretical and managerial implications}

The results presented in this study offer theoretical contributions to the existing body of literature on usage of e-banking services. As a response to Bagozzi's (2007) call for alternative theoretical mechanisms in order to foster progress in the mature stream of IS, the integration of relationship commitment, relationship trust and price value provides fresh impetus in the intention-based theoretical domain. The integrated model, which incorporated additional marketing components, namely perceived price value, relationship trust and relationship commitment, in the TAM to study e-banking continued usage intentions, adds an empirical contribution in literature. The integrated model demonstrated high explanatory power, as attitude towards e-banking is explained by up to $62 \%$ of the variance, and continued usage intentions is explained by up to $52 \%$ of the variance. Furthermore, the findings augment and support existing empirical work in the technology adoption and usage literature (Brown \& Molla 2004; Maduku \& Mpinganjira 2012; Matikiti, Mpinganjira \& Roberts-Lombard 2018; Nel \& Boshoff 2014; Redlinghuis \& Rensleigh 2010; Shen 2015), namely that attitudes strongly influence the intention to continue using a particular technology. Hence, if customers have a positive attitude towards using e-banking, they will want to continue using it. Particularly, the results found that customer's perceptions related to ease of use and usefulness of e-banking have a significant effect on e-banking attitude. These results have managerial implications for retail banks, in the sense that they have a responsibility to provide all the necessary or valuable information and continuous customer education, to improve users' perceptions on how to use e-banking and its usefulness. This will, in turn, positively shape customers' attitudes towards using e-banking and towards continuing to use the services.

\section{Conclusion and recommendations}

The results revealed in this study suggest that the salient beliefs of technology acceptance (perceived ease of use and perceived usefulness) are influential in determining attitudes towards e-banking continued usage intentions. Despite the fact that the prediction analysis did not find relationship commitment and relationship trust to be statistically significant in influencing customers' attitude, it is argued that retail banks should strive to foster relationship commitment and relationship trust with their customers. Retail banks should also invest more effort in reducing negative perceptions around the price value of e-banking. These recommendations are based on the results from the descriptive statistics, where it became clear that most respondents tended to agree with the scale items that measured relationship commitment, relationship trust and perceived price value. These recommendations are also based on the empirical support from the correlation matrix, which revealed that the research constructs were all positive and statistically significant at the 0.01 level, which means that there is a $99 \%$ chance that these correlations do exist. Hence, there is a need for retail banks to not only focus on augmenting the two customer beliefs (perceived ease of use and perceived usefulness) but 
also consider working on building relationship commitment and relationship trust.

\section{Acknowledgements}

The authors wish to acknowledge all the authors whose work has been cited in this manuscript, as well as the Banking Sector Education and Training Authority (BANKSETA) and Central University of Technology, Free State, for funding this project. The views expressed in this article, however, are those of the authors and not those of the funders. This article was language-edited by a freelance language editor, Anthony Sparg. He has edited several academic journal articles in the field of marketing. He has an MA cum laude in African Languages (isiXhosa), an MA cum laude in Linguistics and a Higher Diploma in Education.

\section{Competing interests}

The authors declare that they have no financial or personal relationships that may have inappropriately influenced them in writing this article.

\section{Authors' contribution}

A.N. was the principal investigator and was responsible for the conceptualisation of the study, while M.T. and F.v.d.W. made conceptual contributions during the final write-up of the article.

\section{References}

Adam, M.H.M., 2013, 'Electronic banking problems and opportunities: The Sudanese context', European Journal of Business and Management 5(22), 55-66.

Agwu, M.E., 2015, 'Analysis of obstacles to uptake of internet banking services in Nigeria', Research Journal of Business and Management 2(1), 99-114.

Ali, F., Amin, M. \& Ryu, K., 2015, 'The role of physical environment, price perceptions, and consumption emotions in developing customer satisfaction in Chinese resort hotels', Journal of Quality Assurance in Hospitality \& Tourism 17(1), 45-70. https://doi.org/10.1080/1528008X.2015.1016595

Bagozzi, R.P., 2007, 'The legacy of the technology acceptance model and a proposal for a paradigm shift', Journal of the Association for Information Systems 8(4), 244-254. https://doi.org/10.17705/1jais.00122

Berndt, A. \& Tait, M., 2014, Relationship marketing and customer relationship marketing, 3th edn., Juta and Company Ltd, Cape Town.

Black, K., 2011, Business statistics for contemporary decision making, Prentice-Hall, New York.

Brown, I. \& Molla, A., 2004, 'Determinants of Internet and cell phone banking adoption in South Africa', Journal of Internet Banking and Commerce, viewed 20 June 2017, from http://www.icommercecentral.com/open-access/determinantsof-internet-and-cell-phone-banking-adoption-in-south-africa.pdf

Buttle, F., 2009, Customer relationship management: Concepts and technologies, 2nd edn., Butterworth-Heinemann, Burlington.

Davis, F.D., 1989, 'Perceived usefulness, perceived ease of use, and user acceptance of information technology', MIS Quarterly 13(3), 319-340. https://doi.org/10. 2307/249008

Egan, J., 2011, Relationship marketing: Exploring relational strategies in marketing 4th edn, Pearson Education Limited, Edinburgh Gate.

Field, A., 2013, Discovering statistics using IBM SPSS statistics, Sage, Thousand Oaks, CA.

Finscope South Africa, 2015, Consumer survey, viewed 21 June 2017, from http:// www.finmark.org.za/wpcontent/uploads/2016/03/Broch_FinScopeSA2015_ Consumersurvey_FNL.pdf

Green, S. \& Van Belle, J.P., 2003, 'Customer expectations of Internet Banking in South Africa', Proceedings of the Third International Conference on Electronic Business (ICEB), Singapore, 9-13 December 2003, pp. 283-285.

Hair, J.F., Black, W.C., Babin, B.J. \& Anderson, R.E., 2014, Multivariate data analysis, 7th edn., Pearson, Edinburgh Gate.

lacobucci, D. \& Churchill, G.A., Jr., 2010, Marketing research: Methodological foundations, 10th edn., South-Western Cengage Learning, Mason, IA.
Jara, A.J., Parra, M.C. \& Skarmeta, A.F., 2014, 'Participative marketing: Extending social media marketing through the identification and interaction capabilities from the Internet of things', Personal and Ubiquitous Computing 18(4), 997-1011. from the Internet of things', Personal and Ubiqui
https://doi.org/10.1007/s00779-013-0714-7

Keivani, F.S., Jouzbarkand, M., Khodadadi, M. \& Sourkouhi, Z.K., 2012, 'A general view on the e-banking', International Proceedings of Economics Development and Research, 62-65, viewed 13 June 2017, from http://www.ipedr.com/vol43/013ICFME2012-M00033.pdf

Khater, A.H., Almansour, B.A. \& Mahmoud, M.H., 2016, 'Factors influencing customers' acceptance of Internet banking services in Sudan', International Journal of Science and Research 5(1), 1429-1433.

Kotler, P., Armstrong, G. \& Tait, M., 2010, Principles of marketing: Global and southern African perspectives, Pearson Education South Africa, Cape Town.

Lamb, C.W., Hair, J.F., McDaniel, C., Boshoff, C., Terblanche, N.S., Elliot, R. et al., 2015, Marketing, 5th South African edn., Oxford University Press Southern Africa, Cape Town

Lester, F.K., 2007, Second handbook of research on mathematics teaching and learning, New Age, New York.

Maduku, D.K., 2013, 'Predicting retail banking customers' attitude towards internet banking services in South Africa', Southern African Business Review 17(3), 76-100. https://doi.org/10.4102/sajems.v19i4.1558

Maduku, D.K., 2016, 'The effect of institutional trust on Internet banking acceptance: Perspectives of South African banking retail customers', South African Journal of Economic and Management Sciences 19(4), 533-548. https://doi.org/10.4102/ sajems.v19i4.1558

Maduku, D.K. \& Mpinganjira, M., 2012, 'An empirical investigation into customers' attitude towards usage of cell phone banking in Gauteng, South Africa', Journal of Contemporary Management 9(1), 172-189.

Malhotra, N.K., 2010, Marketing research: An applied orientation, 6th edn., Prentice Hall, Upper Saddle River, NJ.

Matikiti, R., Mpinganjira, M. \& Roberts-Lombard, M., 2018, 'Application of the technology acceptance model and the technology-organisation-environment model to examine social media marketing use in the South African tourism industry', South African Journal of Information Management 20(1), 1-12. https:// doi.org/10.4102/sajim.v20i1.790

McDaniel, C., Lamb, C.W. \& Hair, J.F., 2006, Introduction to marketing, 8th edn., Thomson South-Western, London.

Mlitwa, N. \& Tshetsha, N., 2012, 'Adoption of cell-phone banking among low-income communities in rural areas of South Africa', iBusiness 4(4), 362-370. https://doi. communities in rural areas
org/10.4236/ib.2012.44045

Moodley, T. \& Govender, I., 2016, 'Factors influencing academic use of internet banking services: An empirical study', African Journal of Science, Technology, Innovation and Development 8(1), 43-51. https://doi.org/10.1080/20421338.2015.1128043

Morgan, R.M. \& Hunt, S.D., 1994, 'The commitment-trust theory of relationship marketing', Journal of Marketing 58(3), 20-38.

Mpinganjira, M., Dos Santos, M.A.O., Botha, E., Du Toit, D., Erasmus, A.C., Maree, T. et al., 2013, Consumer behaviour: South African psychology and marketing applications, Oxford University Press Southern Africa, Cape Town.

Nach, E.J., 2009, Instructional Use of Research-Based Practices for Students with Autism Spectrum Disorder, ProQuest LLC, Michigan, MI.

Nel, J. \& Boshoff, C., 2014, 'Enhancing the use of internet banking in an emerging market', South African Journal of Economic and Management Sciences 17(5), 624-638. https://doi.org/10.4102/sajems.v17i5.775

Nel, J., Boshoff, C. \& Raleting, T., 2012, 'Exploiting the technology cluster effect to enhance the adoption of WIG mobile banking among low-income earners', Management Dynamics 21(1), 30-44

Pavlou, P.A. \& Fygenson, M., 2006, 'Understanding and predicting electronic commerce adoption: An extension of the theory of planned behavior', MIS Quarterly 30(1), 115-143. https://doi.org/10.2307/25148720

Ramavhona, T.C. \& Mokwena, S., 2016, 'Factors influencing Internet banking adoption in South African rural areas', South African Journal of Information Management 18(2), 1-8. https://doi.org/10.4102/sajim.v18i2.642

Redlinghuis, A. \& Rensleigh, C., 2010, 'Customer perceptions on Internet banking information protection', South African Journal of Information Management 12(1), 1-6. https://doi.org/10.4102/sajim.v12i1.444

Roberts-Lombard, M. \& Parumasur, S.B., 2017, Consumer behaviour, 4th edn, Juta, Cape Town.

Sahoo, D. \& Pillai, S.S., 2017, 'Role of mobile banking servicescape on customer attitude and engagement: An empirical investigation in India', International Journal of Bank Marketing 35(7), 1115-1132. https://doi.org/10.1108/IJBM-09-2015-0144

Schiffman, L.G., Kanuk, L.L. \& Wisenblit, J., 2010, Consumer behavior, 10th edn., Prentice Hall, Upper Saddle River, NJ.

Shen, G.C., 2015, 'How quality of life affects intention to use social networking sites: Moderating role of self-disclosure', Journal of Electronic Commerce Research 16(4), 276-289.

Singh, A.M., 2004, 'Trends in South African Internet banking', Aslib Proceedings: New Information Perspectives 56(3), 187-196. https://doi.org/10.1108/000125304 10539368

Singh, S. \& Srivastava, R.K., 2018, 'Predicting the intention to use mobile banking in India', International Journal of Bank Marketing 36(2), 357-378. https://doi. org/10.1108/IJBM-12-2016-0186

Statistics South Africa, 2015, General household survey, viewed 21 April 2018, from https://www.statssa.gov.za/publications/P0318/P03182015.pdf 
Tien, C.C., 2009, 'What is the truth in market research? Being truth teller', Asian Journal al of Management and Humanity Sciences 4(4), 241-258.

Tran, H.T.T. \& Corner, J., 2016, 'The impact of communication channels on mobile banking adoption', International Journal of Bank Marketing 34(1), 78-109.

Venkatesh, A., Thong, J.Y.L. \& Xu, X., 2012, 'Consumer acceptance and use of information technology: Extending the unified theory of acceptance and use of technology', MIS Quarterly 36(1), 157-178.
Wahab, S., Noor, N.A.M., Ali, J. \& Jusoff, K., 2009, 'Relationship between customer relation management performance and e-banking adoption: A look at Malaysian banking industry', International Journal of Business and Management 4(2), 122-128. https://doi.org/10.5539/ijbm.v4n12p122

World Wide Worx, 2004, Online Banking in South Africa 2004, viewed 23 April 2016 , from http://www.theworx.biz/bank04.htm.

Yu, J. \& Guo, C., 2008, 'An exploratory study of ubiquitous technology in retail banking', Academy of Commercial Banking and Finance 8(1), 7-12. 